\title{
Urgences
}

\section{Elle s'étire...}

\section{Danielle Grenier}

Numéro 13, mars 1986

\section{Éclats d'atelier}

URI : https://id.erudit.org/iderudit/025228ar

DOI : https://doi.org/10.7202/025228ar

Aller au sommaire du numéro

\section{Éditeur(s)}

Urgences

\section{ISSN}

0226-9554 (imprimé)

1927-3924 (numérique)

Découvrir la revue

\section{Citer ce document}

Grenier, D. (1986). Elle s'étire... Urgences, (13), 63-64.

https://doi.org/10.7202/025228ar

Ce document est protégé par la loi sur le droit d'auteur. L'utilisation des services d'Érudit (y compris la reproduction) est assujettie à sa politique d'utilisation que vous pouvez consulter en ligne.

https://apropos.erudit.org/fr/usagers/politique-dutilisation/ 


\section{Danielle Grenier}

Elle s'étire doucement, le geste nonchalant, et renverse un pied qu'elle appuie sur la malle rectangulaire et brune. Tout à côté, un enfant pose sa tête contre l'épaule noire d'un homme. Elle observe ce mouvement qui lui crée un silence à̀ la hauteur de son ventre.

Le manteau bleu qu'elle porte est légèrement entrouvert. Elle ne sait pas bien si elle a chaud ou froid. Mais il y a beaucoup de monde dans cette salle, et les portes qui s'ouvrent, se referment trop lentement. Deux longues femmes prennent place près d'elle. Qu'il fasse chaud ou froid, elle étouffe un peu. Quelqu'un fait obstacle à son regard et lui cache en partie l'horloge murale. Elle ne distingue que l'aiguille des minutes. "Vous avez l'heure?" Une bouche avec des lèvres très fines, des yeux charmants. Elle regarde une seconde fois I'horloge. "Presque moins quart", répond-elle.

Elle ramène un pan de son manteau qu'elle colle plus étroitement à son corps impatient. Elle se dit qu'elle aurait pris I'avion que ça aurait été pareil. Elle s'étonne de la lenteur des aiguilles dentelées de l'horloge. Elle entend un gémissement lointain, un écho plaintif qui annonce l'arrivée du train. Déjà les gens franchissent le seuil de la gare, pour attendre dehors, sur le quai. Elle ne se lève pas. Pourtant elle se lèvera. L'enfant serre bien fort contre lui un vieil ourson usé. Le jeune homme qui l'accompagne prend sa main, ils se dirigent eux ausi vers la porte. Alors elle se lève, déséquilibrant la petite valise sur laquelle elle avait posé le pied.

Elle dépose son manteau sur le siège qu'on lui a assigné et pense qu'il y a des voyages qui n'en sont pas. Pourtant, elle aime le roulis grinçant du train. A la petite école, elle s'en souvient, dans son petit catéchisme, il y avait des tas d'images, anges blonds et frisés, démons rouges et cornus. Pas une pour les enfants mort-nés. Rien, mais dans sa 
tête, ils étaient suspendus indéfiniment dans le vide. Langés dans une brume grise, ils flottaient tous ensemble dans un non-lieu de l'univers qu'on appelait les limbes. Petite communauté en attente. Non, ce n'est pas le voyage qui est long, c'est cet interminable flottement. Pour le train, le même parcours, le même horaire. Pour elle, autre chose.

Elle a les yeux mi-clos, la tête presque appuyée à la vitre fraîche. Elle sait qu'elle est enceinte depuis une semaine. A peine. Non, ce n'est pas le voyage qui démesure le temps, la distance à parcourir. Seulement l'insupportable de l'attente, quelle que soit la distance à parcourir. 